\title{
Antidiabetic and hypolipidemic activities of hydroethanolic root extract of Uvaria chamae in streptozotocin induced diabetic albino rats
}

Jonathan Emeka Emordi ${ }^{*}$, Esther Oluwatoyin Agbaje ${ }^{2}$, Ibrahim Adekunle Oreagba² and Osede Ignis Iribhogbe ${ }^{1}$

\begin{abstract}
Background: Diabetes mellitus is a metabolic disorder of multiple aetiology characterised by hyperglycemia resulting from defects in insulin secretion, insulin action or both. It is a global epidemic ravaging both developed and developing countries. The situation will worsen if nothing is done urgently. In fact, the need to identify natural products with antidiabetic potentials is of great importance as supported by several research efforts all over the world, in search of antidiabetic plant based products that are safe and efficacious. Available literatures show that several phytochemicals with antidiabetic properties have been identified in certain plants amongst which include Uvaria chamae. The potentials of Uvaria chamae as an antidiabetic and hypolipidemic drug-candidate are thus tested.
\end{abstract}

Methods: Diabetes mellitus was experimentally induced after the rats were fasted overnight by administering intraperitoneally, $60 \mathrm{mg} / \mathrm{kg}$ streptozotocin. After $72 \mathrm{~h}$, the rats with plasma glucose levels $>200 \mathrm{mg} / \mathrm{dl}$ were classified as diabetic. A total of six groups containing five rats per group were used. One group of diabetic rats was untreated. Three diabetic groups, each were treated orally with 100, 250 and $400 \mathrm{mg} / \mathrm{kg}$ body weight of the extract. Another diabetic group was treated with insulin $(0.5 \mathrm{IU} / \mathrm{kg})$ subcutaneously. The control received $0.5 \mathrm{ml}$ ( $2 \%$ solution) of acacia orally. The treatment was for 8 days. The effects of the extract on weight, plasma glucose and other biochemical parameters were evaluated using standard procedures.

Results: The diabetic rats treated with the extract showed significant reductions $(p<0.05)$ in weight, plasma glucose levels, low density lipoprotein and cholesterol compared with the control. The 100, 250 and $400 \mathrm{mg} / \mathrm{kg}$ body weight of the extract showed maximum glucose reduction of $85.16,81.50$ and $86.02 \%$ respectively. Histologically the pancreas of the diabetic rats treated with the extract, showed clusters of variably sized regenerated islet of Langerhans within sheets of normal exocrine pancreas, while the pancreas of diabetic rats treated with insulin showed no islet of Langerhans.

Conclusion: The study showed that Uvaria chamae caused weight loss and has good hypoglycemic and hypolipidemic activities that may reduce the risk of developing cardiovascular diseases.

Keywords: Diabetes mellitus, Hypoglycemic effects, Hypolipidemic effects, Streptozotocin, Uvaria chamae

\footnotetext{
* Correspondence: drjonathan.emordi@gmail.com

'Department of Pharmacology and Therapeutics, College of Medicine,

Ambrose Alli University, Ekpoma, Nigeria

Full list of author information is available at the end of the article
}

(c) The Author(s). 2016 Open Access This article is distributed under the terms of the Creative Commons Attribution 4.0 International License (http://creativecommons.org/licenses/by/4.0/), which permits unrestricted use, distribution, and reproduction in any medium, provided you give appropriate credit to the original author(s) and the source, provide a link to the Creative Commons license, and indicate if changes were made. The Creative Commons Public Domain Dedication waiver (http://creativecommons.org/publicdomain/zero/1.0/) applies to the data made available in this article, unless otherwise stated. 


\section{Background}

Diabetes mellitus has been described as a metabolic disorder of multiple aetiology, and characterized by chronic hyperglycemia with disturbances of carbohydrate, fat, and protein metabolism, resulting from defects in insulin secretion, insulin action or both $[1,2]$. It is one of the oldest diseases of mankind that affects millions of people worldwide [3]. The number of people living with the disease is expected to double with major impact on the population of the developing countries due to increased rate of industrialization $[3,4]$. It is a major risk factor for the development of cardiovascular disease [5]. Hence, the need to reduce the risk of vascular complications by securing adequate glycemic, lipidemic, blood pressure and weight control [6]. Currently diabetes is controlled by diet, exercise, oral hypoglycemic agents and insulin therapy [7]. The high level of treatment failures, unpleasant side effects and enormous cost associated with diabetic therapy have generated an urgent need and desire for alternative treatments [8]. However, the preferred choice of plant medicine by many might not be unconnected with the historical successes recorded in the use of herbal products in traditional system of medicine in the management of diabetes mellitus [9]. One of such plants used traditionally in the management of diabetes mellitus is Uvaria chamae.

Uvaria chamae is a medicinal plant that belongs to the family, Annonaceae. It is a climbing plant commonly found in West Africa [9]. In this region of the world, it is identified by numerous names such as: Ogholo by the Esan people of Edo state, Ayiloko by the Igalas, Kaskaifi by the Hausas, Oko oja by the Yorubas, Mmimi ohia by the Igbos in Nigeria and Akotompo by the Akan-fante people of Ghana [9]. The health benefits of medicinal plants are attributed in part to their unique phytochemical composition [10]. The phytochemical analysis of the leaves and roots of Uvaria chamae revealed the presence of alkaloids, glycosides, saponin, tannins, flavonoids, terpenoids and phenols $[11,12]$. Our previous study on the preliminary phytochemical screening and evaluation of hypoglycemic properties of Uvaria chamae also revealed that the extract has secondary metabolites such as alkaloids, flavonoids, tannins and terpenoids which corroborate earlier works done on the phytochemical screening of this plant. The study showed that the hypoglycemic properties of Uvaria chamae may be accounted for by the presence of the phytochemicals [9]. The anti-fungal, anti-malarial and antiinflammatory activities of Uvaria chamae have also been reported $[11,13,14]$. However, no scientific study has been conducted on the antidiabetic activity of this plant. The present study therefore was designed to evaluate the antidiabetic and hypolipidemic activities of the hydroethanolic root extract of Uvaria chamae in streptozotocin induced diabetic rats.

\section{Methods}

\section{Plant materials}

The roots of Uvaria chamae were obtained from a farm in Uromi, Edo State, Nigeria during the rainy season. They were authenticated by a taxonomist, $\mathrm{Mr} \mathrm{T}$. K. Odewo, of Department of Botany, University of Lagos, Nigeria. The voucher specimen with number LUH 3572 was deposited in the University herbarium.

\section{Preparation of the plant material for extraction}

The roots were washed with clean water to remove foreign materials, chopped into small pieces and dried in an oven at $45^{\circ}$ centigrade for 4 days. They were ground to coarse powder with electric grinder. The root powder, $500 \mathrm{~g}$, was extracted with $93.3 \%$ hydroethanol by maceration with frequent stirring for 5 days. The extract was filtered using Whatman filter paper number 4 and concentrated with a rotary evaporator at a reduced pressure. The concentrated extract was dried in an oven at $40^{\circ}$ centigrade to obtain $22.41 \mathrm{~g}$ dry residue ( $4.48 \%$ yields).

\section{Animals}

Albino rats $(160 \pm 20 \mathrm{~g})$ of both sexes were obtained from the Laboratory Animal Center, College of Medicine, University of Lagos, Idi-Araba and kept under standard environmental condition of 12/12 h light/dark cycle. They were housed in cages (5 animals per cage), maintained on standard animal pellets (Pfizer Feeds Plc, Nigeria), and

Table 1 Effect of Uvaria chamae on Fasting Blood Glucose (FBG) Levels (mg/dl) and \% Reduction (\% R) of FBG levels

\begin{tabular}{lllcccc}
\hline Group & Day0 & Day1 & Day5 & \%R in Day5 & Day 8 & \%R in Day8 \\
\hline I & $74.33 \pm 0.88$ & $75.66 \pm 2.19$ & $86.00 \pm 3.22$ & $\ldots \ldots .67 \pm 6.17$ & 2.6. \\
II & $59.33 \pm 2.91$ & $363.00 \pm 50.5^{*}$ & $270.70 \pm 33.17^{*}$ & 25.43 & $133.30 \pm 10.04^{*}$ & 63.28 \\
III & $63.33 \pm 0.67$ & $303.00 \pm 7.10^{*}$ & $44.00 \pm 7.00^{*}$ & 85.48 & $42.37 \pm 0.52^{*}$ & 86.02 \\
IV & $54.67 \pm 1.45$ & $263.30 \pm 3.84^{*}$ & $52.67 \pm 7.27^{*}$ & 80.00 & $48.70 \pm 1.04^{*}$ & 81.50 \\
V & $66.67 \pm 3.93$ & $325.70 \pm 17.85^{*}$ & $46.00 \pm 2.08^{*}$ & 85.16 & $48.33 \pm 0.88^{*}$ & 85.16 \\
VI & $60.00 \pm 4.36$ & $242.30 \pm 3.93^{*}$ & $256.30 \pm 1.86^{*}$ & -5.66 & $300.30 \pm 2.03^{*}$ & -23.94 \\
\hline
\end{tabular}

*Significant difference $(p<0.05 ; n=5)$ between the Mean \pm SEM of test group vs. control. Group I= (control) Normal rats received $0.5 \mathrm{ml}(2 \%$ solution) of acacia, $\mathrm{II}=$ diabetic rats treated with insulin $0.5 \mathrm{I} . \mathrm{U} / \mathrm{kg}, \mathrm{III}=$ diabetic rats treated with $400 \mathrm{mg} / \mathrm{kg}$ extract, IV = diabetic rats treated with $250 \mathrm{mg} / \mathrm{kg}$ extract, $\mathrm{V}=$ diabetic rats treated with $100 \mathrm{mg} / \mathrm{kg}$ extract, $\mathrm{VI}=$ diabetic rats untreated 
Table 2 Effect of Uvaria chamae on Plasma Lipid Profile $(\mathrm{mg} / \mathrm{dl})$

\begin{tabular}{lllllcc}
\hline Parameter & Group I & Groupll & Grouplll & GrouplV & GroupV & Group VI \\
\hline Chol & $126.3 \pm 2.3$ & $78.0 \pm 0.6^{*}$ & $72.3 \pm 0.9^{*}$ & $70.0 \pm 14.4^{*}$ & $89.33 \pm 0.9^{*}$ & $107.0 \pm 0.6$ \\
TG & $43.2 \pm 0.6$ & $42.3 \pm 1.9$ & $57.3 \pm 8.2$ & $34.7 \pm 0.3$ & $61.3 \pm 1.9$ & $73.7 \pm 0.9^{*}$ \\
HDL & $24.4 \pm 0.4$ & $25.3 \pm 1.9$ & $36.3 \pm 4.1$ & $31.7 \pm 0.9$ & $30.7 \pm 0.7$ & $29.7 \pm 1.5$ \\
LDL & $93.3 \pm 0.6$ & $44.2 \pm 1.9^{*}$ & $24.5 \pm 7.8^{*}$ & $31.36 \pm 7.13^{*}$ & $46.37 \pm 1.53^{*}$ & $62.56 \pm 2.52$ \\
\hline
\end{tabular}

*significant difference $(p<0.05 ; n=5)$ between the Mean \pm SEM of test group vs. control. Group I = (control) Normal rats received $0.5 \mathrm{ml}(2 \%$ solution) of acacia, $\mathrm{II}=$ diabetic rats treated with insulin $0.5 \mathrm{I} . \mathrm{U} / \mathrm{kg}, \mathrm{III}=$ diabetic rats treated with $400 \mathrm{mg} / \mathrm{kg}$ extracts, IV = diabetic rats treated with $250 \mathrm{mg} / \mathrm{kg}$ extract, $\mathrm{V}=$ diabetic rats treated with $100 \mathrm{mg} / \mathrm{kg}$ extracts, $\mathrm{Vl}=$ diabetic rats untreated

provided with water ad libitum. They were allowed to acclimatize for 7 days to the laboratory conditions before the experiment. The use and care of the animals, and the experimental protocol were in strict compliance with the National Research Council guidelines on the care and use of laboratory animals [15]. The experimental protocol (with Protocol ID: RGEEC/21/2015) was approved by the research grants and experimentation Ethics committee of the College of Medicine, University of Lagos, Nigeria.

\section{Diabetic study}

The dose selection for the diabetic study was guided by the result obtained from the oral acute toxicity study done in our previous work which showed that the median lethal dose was $7.08 \mathrm{~g} / \mathrm{kg}$ body weight [9].

Diabetes mellitus was experimentally induced in the rats after an overnight fast by administering intraperitoneally (IP) $60 \mathrm{mg} / \mathrm{kg}$ streptozotocin dissolved in $0.1 \mathrm{M}$ citrate buffer of PH 4.5 [16]. After $72 \mathrm{~h}$, the blood glucose levels were monitored with a glucometer (AccuChek, Roche Diagnostics) and the rats with plasma glucose levels $>200 \mathrm{mg} / \mathrm{dl}$ were classified as diabetic [17] and were included in the study. A total of six groups containing five rats per group were used. Five groups were diabetic while the remaining group was used as a control. The rats were treated daily for 8 days orally except for those that were given insulin subcutaneously. The treatment was as follows:

Group I: control given $0.5 \mathrm{ml}$ ( $2 \%$ solution) of acacia
Group II: Induced diabetic rats treated daily subcutaneously with (soluble) insulin 0.5 I.U / kg body weight

Group III: Induced diabetic rats treated daily with $400 \mathrm{mg} / \mathrm{kg}$ of the extract

Group IV: Induced diabetic rats treated daily with $250 \mathrm{mg} / \mathrm{kg}$ of the extract

Group V: Induced diabetic rats treated daily with $100 \mathrm{mg} / \mathrm{kg}$ of the extract

Group VI: Induced diabetic rats untreated

The rats were weighed and blood samples were collected from the tail vein for fasting blood glucose levels from the beginning of the treatment, the $5^{\text {th }}$ day and at the end of the treatment (the $8^{\text {th }}$ day). On the $8^{\text {th }}$ day, blood was obtained via ocular puncture into heparinised containers for biochemical profile.

\section{Sample analysis}

The heparinised blood was centrifuged within 5 min of collection at $4000 \mathrm{~g}$ for $10 \mathrm{~min}$ to obtain plasma, that was analysed for total cholesterol (Chol), triglyceride (TG), and High density lipoprotein-cholesterol (HDL-cholesterol) levels by modified enzymatic procedures from Sigma Diagnostics [18]. Low density lipoprotein-cholesterol (LDL-cholesterol) levels were calculated using the Friedwald equation [19]. Plasma was analysed for alanine aminotransferase (ALT), aspartate aminotransferase (AST), alkaline phosphatase (ALP) and creatinine by standard enzymatic assay analysis [20]. The plasma protein contents and plasma

Table 3 Effect of Uvaria chamae on other biochemical parameters on the $8^{\text {th }}$ Day

\begin{tabular}{lcccccc}
\hline Parameter & Group I & Group II & Grouplll & GrouplV & GroupV & Group VI \\
\hline Protein $(\mathrm{g} / \mathrm{L})$ & $34.9 \pm 0.1$ & $25.7 \pm 0.9$ & $20.0 \pm 2.3^{*}$ & $35.0 \pm 1.2$ & $23.7 \pm 0.3$ & $15.0 \pm 2.0^{*}$ \\
ALB $(\mathrm{mg} / \mathrm{dl})$ & $43.9 \pm 0.3$ & $25.3 \pm 1.5^{*}$ & $16.3 \pm 1.5^{*}$ & $37.3 \pm 0.9$ & $27.0 \pm 0.6$ & $33.3 \pm 1.2$ \\
Creatinine $(\mathrm{mg} / \mathrm{dl})$ & $0.6 \pm 0.01$ & $1.0 \pm 0.03$ & $1.0 \pm 0.1$ & $1.03 \pm 0.2$ & $0.8 \pm 0.1$ & $1.13 \pm 0.1^{*}$ \\
Urea $\mathrm{mg} / \mathrm{dl}$ & $27.7 \pm 0.9$ & $56.0 \pm 0.6^{*}$ & $64.0 \pm 0.6^{*}$ & $43.3 \pm 0.9^{*}$ & $31.0 \pm 0.6$ & $46.3 \pm 2.3^{*}$ \\
AST $(\mathrm{U} / \mathrm{L})$ & $12.6 \pm 0.2$ & $27.2 \pm 0.2^{*}$ & $13.3 \pm 2.2$ & $16.3 \pm 0.3$ & $13.8 \pm 0.2$ & $31.1 \pm 1.8^{*}$ \\
ALT $(\mathrm{U} / \mathrm{L})$ & $10.8 \pm 0.5$ & $22.3 \pm 1.3^{*}$ & $11.3 \pm 2.2$ & $14.8 \pm 0.4$ & $12.8 \pm 0.4$ & $27.7 \pm 0.7^{*}$ \\
ALP $(\mathrm{U} / \mathrm{L})$ & $13.0 \pm 0.3$ & $30.7 \pm 0.7^{*}$ & $14.7 \pm 2.3$ & $23.7 \pm 5.7$ & $16.7 \pm 1.2$ & $17.8 \pm 0.03$ \\
\hline
\end{tabular}

*Significant difference $(p<0.05 ; n=5)$ between the Mean \pm SEM of test group vs. control. Group I = (control) Normal rats received $0.5 \mathrm{ml}(2 \%$ solution) of acacia, $\mathrm{II}=$ diabetic rats treated with insulin $0.5 \mathrm{I} . \mathrm{U} / \mathrm{kg}$, III = diabetic rats treated with $400 \mathrm{mg} / \mathrm{kg}$ extract, IV = diabetic rats treated with $250 \mathrm{mg} / \mathrm{kg}$ extract, $\mathrm{V}=$ diabetic rats treated with $100 \mathrm{mg} / \mathrm{kg}$ extract, $\mathrm{Vl}=$ diabetic rats untreated 
Table 4 Effect of Uvaria chamae on the body weight (g)

\begin{tabular}{llll}
\hline Group & Day1 & Day5 & Day8 \\
\hline I & $130.7 \pm 17.9$ & $135.7 \pm 20.5$ & $159.0 \pm 2.1$ \\
II & $137.7 \pm 5.8$ & $127.3 \pm 16.8$ & $167.0 \pm 3.5$ \\
III & $133.7 \pm 5.6$ & $140.0 \pm 6.1$ & $122.7 \pm 9.3^{*}$ \\
IV & $121.0 \pm 4.4$ & $107.7 \pm 4.1$ & $102.3 \pm 1.5^{*}$ \\
V & $124.0 \pm 7.2$ & $118.3 \pm 7.1$ & $120.0 \pm 2.9^{*}$ \\
VI & $135.0 \pm 6.4$ & $124.0 \pm 2.7$ & $118.3 \pm 3.5^{*}$ \\
\hline
\end{tabular}

*Significant difference $(p<0.05 ; n=5)$ between the Mean \pm SEM of test group vs. control. Group I = (control) Normal rats received $0.5 \mathrm{ml}$ ( $2 \%$ solution) of acacia, II = diabetic rats treated with insulin $0.51 . \mathrm{U} / \mathrm{kg}, \mathrm{III}=$ diabetic rats treated with $400 \mathrm{mg} / \mathrm{kg}$ extract, IV = diabetic rats treated with $250 \mathrm{mg} / \mathrm{kg}$ extract, $\mathrm{V}=$ diabetic rats treated with $100 \mathrm{mg} / \mathrm{kg}$ extracts, $\mathrm{VI}=$ diabetic rats untreated

glucose contents were determined using enzymatic spectroscopic methods [21].

\section{Tissue histology}

The pancreatic tissue harvested from each group was fixed in $10 \%$ buffered formalin for 7 days before subjecting the tissues to routine histological processing techniques as described by Grizzle et al. [22] and staining with Haematoxylin and Eosin ( $\mathrm{H}$ and $\mathrm{E})$. Each section was examined under light microscope at high power magnification $(\times 100$ and $\mathrm{x} 400)$ for structural changes. Photomicrographs were taken using an attached digital camera.

\section{Statistical analysis}

Data analysis was done using Graph Pad Prism 6. One way analysis of variance (ANOVA) was used to compare means. One-way ANOVA was done followed by Dunnett's multiple comparisons test of treated groups with control. The results were expressed as Mean \pm SEM. Level of significance was set at $p<0.05$.

\section{Results}

Antidiabetic activity of the root extract of Uvaria chamae Table 1 is a summary of the results of the effect of the extract on the fasting blood glucose. There was an astronomical increase in the plasma blood glucose levels of the streptozotocin induced diabetic rats untreated compared with the control from day one to the last day of the experiment. There was also a significant $(p<0.05)$ increase in the plasma glucose levels of the diabetic rats treated with the extract and reference drug insulin compared with the control on day one. This showed that the rats were truly diabetic. However, on the $5^{\text {th }}$ and $8^{\text {th }}$ day (the last day of the experiment), there was a significant $(p<0.05)$ reduction of the plasma glucose levels of the diabetic rats treated with the extract compared with the control. While the plasma blood glucose levels of the diabetic rats treated with insulin was significantly $(p<0.05)$ increased compared with the control on the $5^{\text {th }}$ and $8^{\text {th }}$ day. The rats treated with 100,250 and $400 \mathrm{mg} / \mathrm{kg}$ body weight of the extract showed a glucose reduction of $85.88,80.00$ and $85.48 \%$ respectively on the $5^{\text {th }}$ day. However, on the $8^{\text {th }}$ day of the treatment, rats treated with 100, 250 and $400 \mathrm{mg} / \mathrm{kg}$ body weight of the extract showed a maximum glucose reduction of $85.16,81.50$ and $86.02 \%$ respectively. While the rats treated with the reference drug insulin at the dose of $0.5 \mathrm{IU} / \mathrm{kg}$ body weight showed a glucose reduction of 25.43 and $63.28 \%$ on the $5^{\text {th }}$ and $8^{\text {th }}$ day respectively.

\section{Effect of Uvaria chamae on plasma lipid profile}

Table 2 is a summary of the results of the effects of Uvaria chamae on plasma lipid profile in diabetic rats. The plasma cholesterol and LDL levels of diabetic rats treated with the extracts were significantly reduced $(p<0.05)$ compared with the control. However, there was an increase in the HDL levels. The increase was not significant compared with the control. There was also a significant reduction $(p<0.05)$ in the plasma cholesterol and LDL levels of the diabetic rats treated with insulin. The plasma triglyceride levels of the diabetic rats untreated was significantly increased $(p<0.05)$ compared with the control.

Effect of Uvaria chamae on other biochemical parameters Table 3 is the summary of the result of the effects of Uvaria chamae on the other biochemical parameters. There was a significant decrease $(p<0.05)$ in the plasma protein levels of the diabetic rats treated with $400 \mathrm{mg} / \mathrm{kg}$

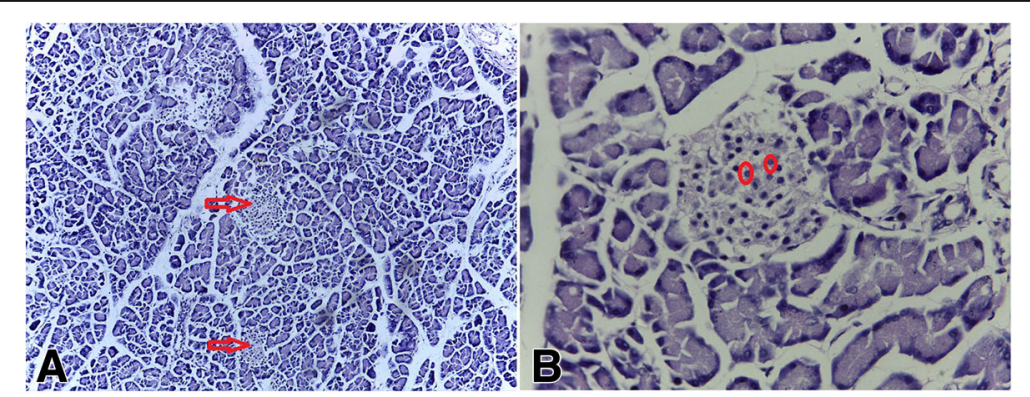

Fig. 1 Photomicrograph of the pancreas of normal rat (positive control); H\&E x100-A and X400-B showing Islet of Langerhans in plate a (Red arrow) and intact islet cells in plate $\mathbf{b}$ (encircled) 


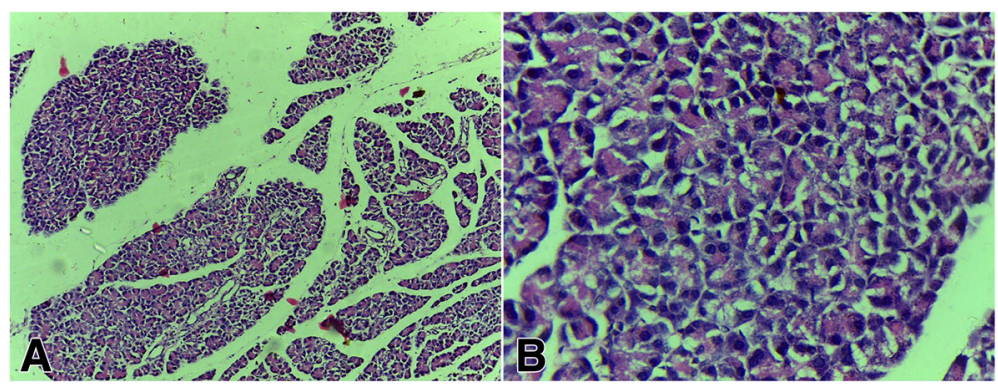

Fig. 2 Photomicrograph of the pancreas of diabetic rat untreated (negative control); H\&E $\times 100$ a and $\times 400$ b with no Islet of Langerhans

of the extract and the diabetic rats untreated compared with the control. The plasma albumin levels of the diabetic rats treated with insulin and $400 \mathrm{mg} / \mathrm{kg}$ of the extract were significantly reduced $(p<0.05)$ compared with the control. There was a significant increase $(p<0.05)$ in the plasma creatinine levels of the diabetic rats untreated compared with the control. The plasma urea levels of the diabetic rats treated with insulin, $400 \mathrm{mg} / \mathrm{kg}$ and $250 \mathrm{mg} / \mathrm{kg}$ of the extracts were significantly increased $(p<0.05)$ compared with the control. There was also a significant increase $(p<0.05)$ in the plasma urea level of the diabetic rats untreated compared with the control. There was no significant change in the plasma AST, ALT and ALP of the diabetic rats treated with the extract compared with the control. However, there was a significant increase $(p<0.05)$ in the plasma AST, ALT and ALP of the diabetic rats treated with insulin compared with the control. There was also a significant increase in $(p<0.05)$ the plasma AST and ALT levels of the diabetic rats untreated compared with the control.

\section{Effect of Uvaria chamae on the body weight}

The summary of the effects of the extract on the body weight of the rats is shown (Table 4). There was weight reduction in the rats treated with 100 and $250 \mathrm{mg} / \mathrm{kg}$ body weight of the extracts on the $5^{\text {th }}$ day. This weight reduction was not statistically significant. However, on the $8^{\text {th }}$ day there was a significant reduction $(p<0.05)$ in the weight of the rats treated with 100,250 and $400 \mathrm{mg} /$ kg body weight of the extracts compared with the control. The diabetic rats untreated showed a reduction in weight on the $5^{\text {th }}$ day. The weight reduction was significant $(p<0.05)$ on the $8^{\text {th }}$ day.

\section{Histopathological studies}

The photomicrographs showing the histological features of the pancreas are shown in Figs. 1, 2, 3, 4, 5 and 6. The pancreas of the normal rats (Fig. 1) showed sheets of normal sized glands lined by columnar epithelium with basally located nuclei surrounded by vesicular cytoplasm. Interspersed within these glands are islands of normal sized Islet of Langerhans. The pancreas of the diabetic rats untreated (Fig. 2) showed sheets of small sized glands lined by columnar epithelium with basally located nucleus and vesicular cytoplasm. No Islet of Langerhan was seen. The pancreas of the diabetic rats (Figs. 3, 4, and 5), treated with the extract 100, 250 and $400 \mathrm{mg} / \mathrm{kg}$ body weight respectively, showed clusters of variably sized regenerated Islet of Langerhans within sheets of normal exocrine pancreas. However, the pancreas of the diabetic rats treated with insulin (Fig. 6), showed sheets of exocrine glands with parenchymal distortion. No Islet of Langerhan seen.

\section{Discussion}

Diabetes mellitus is a disease that affects the quality of life and life expectancy of its victim's worldwide [23]. Many deaths of diabetic subjects have been attributed to

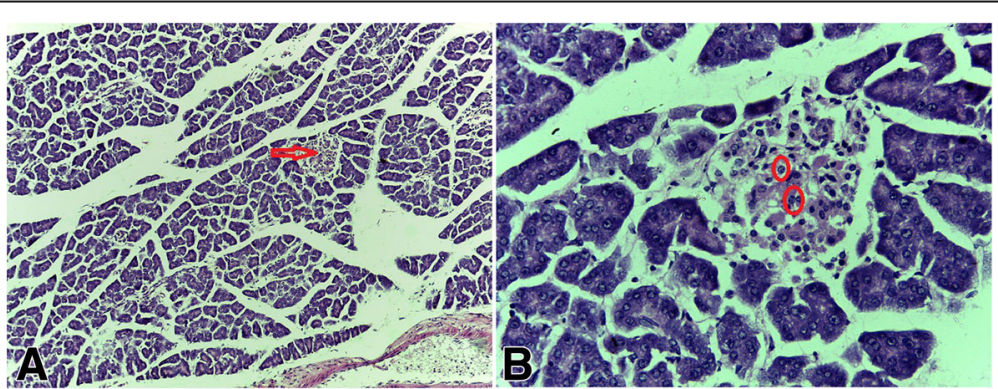

Fig. 3 Photomicrograph of the pancreas of diabetic rat treated with $100 \mathrm{mg} / \mathrm{kg}$ of Uvaria chamae extract (H\&E x100-A and x400-B) showing regenerated cells in the Islet of Langerhans (See plate $\mathbf{a}$; Red arrow) and regenerated islet cells in plate $\mathbf{b}$ (encircled) 


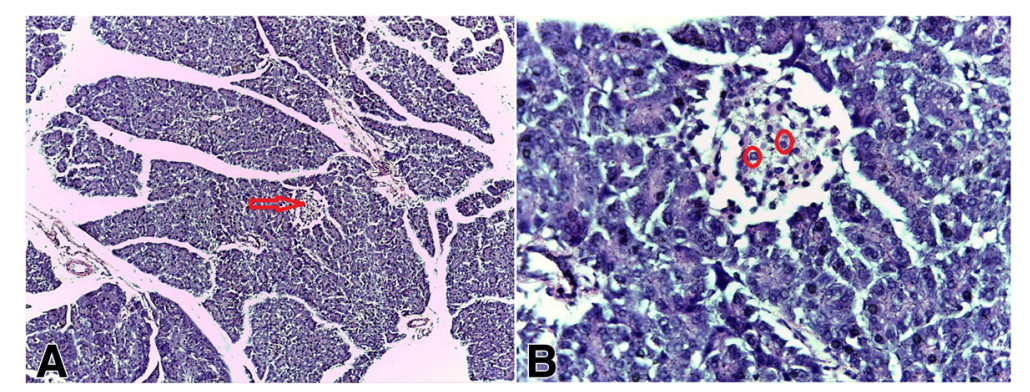

Fig. 4 Photomicrograph of the pancreas of diabetic rat treated with $250 \mathrm{mg} / \mathrm{kg}$ of Uvaria chamae extract (H\&E x100-A and x400-B) showing regenerated cells in the Islet of Langerhans (See plate $\mathbf{a}$; Red arrow) and regenerated islet cells in plate $\mathbf{b}$ (encircled)

hyperglycemia and its accompanied vascular diseases. Hyperglycemia in particular, is the primary clinical manifestation of diabetes [24] and is thought to contribute to diabetic complications by altering vascular cellular metabolism, vascular matrix and circulating lipoproteins [25]. The major goal in the treatment of diabetes has been to keep both short-term and long-term glucose levels within acceptable limits, thereby reducing the risk of long term complications [26].

The result of this study showed that there was a significant reduction in the blood glucose levels of all the diabetic rats treated with the extract compared with the control. The 100, 250 and $400 \mathrm{mg} / \mathrm{kg}$ body weight of the Uvaria chamae extract achieved diabetic control at the $5^{\text {th }}$ day of treatment with a glucose reduction of $85.88,80.00$ and $85.48 \%$ respectively. This diabetic control was maintained till the end of the experiment. This marked reduction in plasma glucose concentration may be as a result of increased release of insulin from regenerated beta cells of the pancreas (Figs. 3, 4 and 5). The presence of phytochemicals such as flavonoids, alkaloids and tannins in the extract as reported in our previous study [9] may also have contributed to its antidiabetic activity.

Besides hyperglycemia, diabetes mellitus is highly characterized by elevated levels of triglycerides and cholesterol in the blood associated with a modern lifestyle and increased consumption of a high fat diet [27]. The reduced absorption of free fatty acids and free cholesterol by inhibition of pancreatic lipase and pancreatic cholesterol esterase reduces hyperlipidemia associated with diabetes mellitus $[28,29]$. This study revealed that the extract lowered the plasma total cholesterol and LDL-cholesterol levels significantly in the treated diabetic rats. This clearly demonstrated the presence of hypolipidemic agents in the extract. The hypolipidemic activity of the extract may be due to the inhibition of pancreatic lipase and pancreatic cholesterol esterase. The reduced plasma LDL-cholesterol reduces the risk of developing cardiovascular disease [30].

Persistent hyperglycemia causes increase in cellular glucose level in tissues undergoing insulin-independent glucose uptake such as eye lens, retina, kidney, and peripheral nerves, leading to secondary late stage diabetic complications. Influx of excess glucose into polyol pathway causes accumulation of sorbitol in the tissues, resulting in hyperosmotic stress to the cells. This is postulated to be the primary cause of diabetic complications which include nephropathy, retinopathy, cataract, and neuropathy [31]. Creatinine is the most commonly used indicator of renal function. A raised plasma level of creatinine is a recognised marker of renal dysfunction [32]. The significant increase in the plasma creatinine levels of the diabetic rats' untreated indicated renal impairment in this group of rats. Therefore, persistent hyperglycemia due to poorly controlled diabetes mellitus may lead to diabetic nephropathy. A number of extra renal

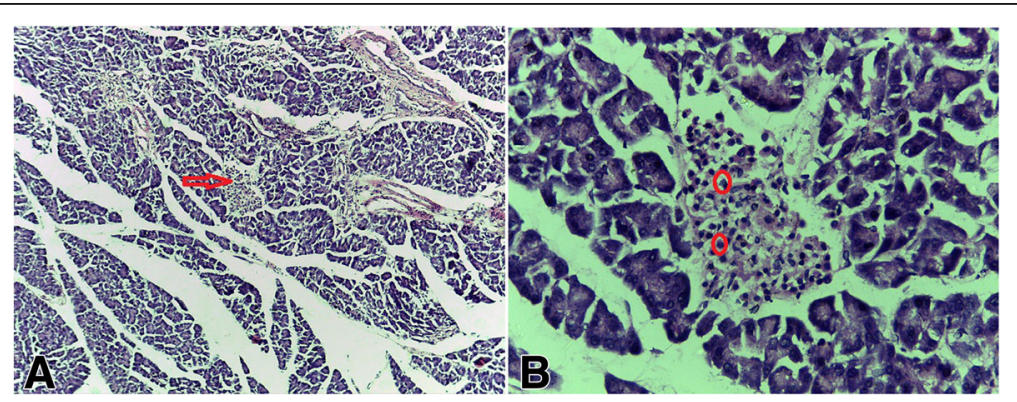

Fig. 5 Photomicrograph of the pancreas of diabetic rat treated with $400 \mathrm{mg} / \mathrm{kg}$ of Uvaria chamae extract (H\&Ex100-A and X400-B) showing regenerated cells in the Islet of Langerhans (See plate $\mathbf{a}$; Red arrow) and regenerated islet cells in plate $\mathbf{b}$ (encircled) 


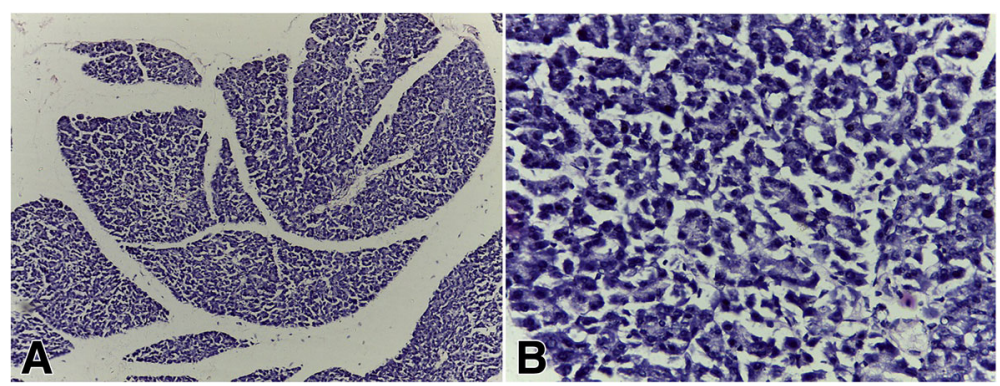

Fig. 6 Photomicrograph of the pancreas of diabetic rat treated with $0.5 \mathrm{IU} / \mathrm{kg}$ of insulin (H\&E $\times 100-\mathbf{a}$ and $\times 400-\mathbf{b}$ ) showing no visible islets

factors influence the circulating urea concentration limiting its value as a test of kidney function. For example plasma urea concentration is increased by high protein diet, increased protein catabolism and dehydration. In the above pre-renal situations, the plasma creatinine concentration is usually normal [33]. The raised plasma urea seen in the diabetic rats treated with insulin and the extract could be as a result of dehydration or induced diabetic state from streptozotocin. This assertion is corroborated by Parvizi et al. [34], who reported that streptozotocin induced diabetes caused a significant increase in serum blood urea nitrogen level in type1 diabetes mellitus. ALT, AST and ALP are part of the liver enzymes [35]. They are frequently used to diagnose or screen for hepatobiliary disease, examine the progression of a disease as well as to monitor or detect the hepatotoxicity that may arise from the use of drugs or substances [36, 37]. The heart also releases AST and ALT, and an elevation in their plasma concentrations is an indicator of liver and heart damage [19]. The results in this study showed that the activities of AST and ALT in the plasma of diabetic rats untreated were markedly elevated. These enzymes are usually found in large quantities in the liver where they play an important role in the metabolism of amino acid [38]. However, as a result of damage or toxicity to the liver, these enzymes may leak from the hepatocytes into the circulation where their levels become elevated [39]. Therefore, the elevated plasma levels of AST and ALT in the diabetic untreated rats suggested liver and heart damage. Administration of the root extract of Uvaria chamae considerably reduced the elevated levels of AST and ALT in the diabetic rats. This showed that the extract is hepatocellular and cardio-protective. However, the elevated levels of AST, ALT and ALP in the diabetic rats treated with insulin during the period of the experiment could be as a result of damage to the liver and the heart from poorly controlled diabetes mellitus. Elevations of transaminases and alkaline phosphatase are common in diabetes mellitus [40]. Weight loss is considered an important aspect of therapy for patients with diabetes. Excess weight places greater direct demand on the beta-cell and also aggravates insulin resistance. Numerous studies have shown that weight loss in patients with diabetes can result in improvement in glucose levels [41]. The results of this study revealed that there was a significant weight reduction in the diabetic rats treated with the extract compared with the control. The weight loss may be due to suppression of appetite.

\section{Conclusion}

This study showed that Uvaria chamae has antidiabetic and hypolipidemic activities. From the study the extract not only improved glycemic and lipidemic control but also caused weight loss, making it beneficial for diabetic patients that are overweight. These findings reduce the risk of developing cardiovascular disease and give credence to the use of the extract traditionally in the treatment of diabetes mellitus. The study also revealed that the extract is hepatocellular and cardio-protective.

\section{Acknowledgements \\ The authors wish to thank Mr M.E Idemudia of Idumu-une Quarters, Uromi, Edo State, Nigeria, for his assistance in plant collection. Authors also wish to thank Dr A.O. Nwaopara, Head of Department, Anatomy, Ambrose Alli University, for his technical assistance. Authors want to specially thank Dr T.A. Azeke, consultant Histopathologist, Irrua Specialist Teaching Hospital for reviewing the histology slides.}

Funding

The research was funded by the authors.

Availability of data and materials

All the data are contained in the manuscript.

\section{Authors' contributions}

EJE, AEO and OIA conceived this study. The experiments were carried out by EJE and IOI. EJE and IOI performed the statistical analysis. EJE drafted the manuscript. The authors read and approved the final manuscript.

\section{Competing interests}

The authors declare that they have no competing interests.

Consent for publication

Authors gave their consent to the publication of this manuscript.

\section{Ethics approval and consent to participate}

The experimental protocol (with Protocol ID: RGEEC/21/2015) was approved by the research grants and experimentation Ethics committee of the College of Medicine, University of Lagos, Nigeria. 


\section{Author details}

'Department of Pharmacology and Therapeutics, College of Medicine, Ambrose Alli University, Ekpoma, Nigeria. ²Department of Pharmacology, Therapeutics and Toxicology, College of Medicine, University of Lagos, Lagos, Nigeria.

Received: 26 December 2015 Accepted: 8 November 2016

Published online: 15 November 2016

\section{References}

1. Alberti KGMM, Zimmet PZ. Definition, diagnosis and classification of diabetes mellitus and its complications. Part 1: Diagnosis and classification of diabetes mellitus. Provisional report of a WHO consultation. Diabet Med. 1998;15:539-53.

2. Kumar P, Clark M. Diabetes mellitus and other disorders of metabolism. Kumar and Clark's Clinical Medicine. 6th ed. Philadelphia: Elsevier Saunders; 2005. p. 1101-51.

3. Wild S, Roglic G, Green A, Sicree R, King H. Global prevalence of Diabetes: estimates for the year 2000 and projections for 2030. Diabetes Care. 2004; 27:1047-53.

4. Sudha P, Zinjarde SS, Bhargava SY, Kumar AR. Potent a-amylase inhibitory activity of Indian Ayurvedic medicinal plants. BMC Complement Altern Med. 2011;11:5. doi:10.1186/1472-6882-11-5.

5. Martin-Timon I, Sevillano-Collantes C, Segura-Galindo A, del Canizo-Gomez FJ. Type2 diabetes and cardiovascular disease: Have all risk factors the same strength? World J Diabetes. 2014:5:444-70.

6. Williams G. Management of non-insulin dependent Diabetes mellitus. Lancet. 1994;343:95-100.

7. Mallick C, Chatterjee K, GuhaBiswas M, Ghosh D. Antihyperglycemic effects of separate and composite extract of root of Musa paradisiacaand leaf of Cocciniaindicain streptozotocin induced diabetic male albino rat. Afr J Tradit Complement Altern Med. 2007;4:362-71.

8. Birru EM, Abdelwuhab M, Shewamene Z. Effect of hydroalcoholic leaves extract of IndigoferaSpicataForssk on blood glucose level of normal, glucose loaded and diabetic rodents. BMC Complement Altern Med. 2015;15:321. doi:10.1186/s12906-015-0852-8

9. Emordi JE, Agbaje EO, Oreagba IA, Iribhogbe OI. Preliminary phytochemical screening and evaluation ofhypoglycemic properties of the root extract of Uveriachamae. Bangladesh J Pharmacol. 2015;10:326-31.

10. Okwu DE, Iroabuchi F. Phytochemical Composition and Biological Activities of Uvariachamae and Clerodendoronsplendens. E-J Chem. 2009;6:553-60.

11. Okwuosa OM, Chukwura El, Chukwuma GO, Okwuosa CN, Enweani IB, Agbakoba NR, et al. Phytochemical and antifungal activities of Uvaria Chamae leaves and roots, spondiasmombin leaves and bark and combretumracemosum leaves. Afr J Med Med Sci. 2012;41(suppl):99-103.

12. Osuagwu GGE, Ihenwosu AO. Phytochemical Composition and Antimicrobial Activity of the Leaves of Alchorneacordifolia (Schum and Thonn), Sansevieraliberica (GerandLabr) and Uvariachamae (P. Beauv). Am J Phytomed Clin Therap. 2014;2:1-12

13. Okokon JE, Ita BN, Udokpo AE. The invivo antimalarial activities of uvariachamae and hippocratea Africana. Ann Trop Med and Parasitol. 2006;100:585-90.

14. Adelodun VO, Elusiayan CA, Olorunmola FO, Adewoyin FB, Omisore NO, Adepiti AO, Agbedahunsi JM, Adewunmi CO. Afr J Tradit Complement Altern Med. 2013;10:469-76.

15. National Research Council (NRC). Guide for the care and use of laboratory animals. 8th ed. Washington, DC: The National Academies Press; 2011.

16. Srinivasan K, Ramarao P. Animal models in type2 diabetes research: an overview. Indian J Med Res. 2007;125:451-72.

17. Qinna NA, Badwan AA. Impact of streptozotocin on altering normal glucose homeostasis during insulin testing in diabetic rats compared to normoglycemic rats. Drug Des Devel Ther. 2015;9:2515-25.

18. Wasan KM, Najafi S, Wong J, Kwong M, Pritchard PH. Assessing plasma lipid levels, body weight and hepatic and renal toxicity following chronic oral administration of a water soluble phytostanol compound FM-VP4, to gerbils. J Pharm Pharm Sci. 2001;4:228-34.

19. Crook MA. Clinical Chemistry and Metabolic Medicine. 7th ed. London: Hodder Arnold; 2006

20. Horder M, Sampson EJ. Approved IFCC recommendation on methods for the measurement of catalytic concentration of enzymes Part 7: IFCC method for creatinine Kinase (ATP: Creatine N-phosphotransferase, EC. 2. 7. 3. 2). Eur J Clin Chem Clin Biochem. 1991;29:435-56.
21. Hussain A, Eshrat HM. Hypoglycemic, hypolipidemic and antioxidant properties of combination of Curcumin from Curcuma longa, Linn and partially purified product from Abromaaugusta, Linn. in streptozotocin induced diabetes. Indian J Clin Biochem. 2002:17:33-43.

22. Grizzle WE, Fredenburgh JL, Myers RB. Fixation of tissues. In: Bancroft JD, Gamble M, editors. Theory and practice of Histological techniques. 6th ed. Philadelphia: Churchill Livingstone, Elsevier Limited; 2008. p. 53-74.

23. Sarkar S, Balhara Y. Diabetes mellitus and Suicide. Indian J Endocrinology Met. 2014:18:468-74

24. Nordestgaard BG, Stender S, Kjeldsen K. Reduces artherogenesis in cholesterol fed Diabetic rabbits. Giant lipoproteins do not enter the arterial wall. Arterioscler. 1988;8:421-8.

25. Barrett- Connor EL, Cohn BA, Wingard DL Edelstein SL. Why is Diabetes mellitus a stronger risk factor for fatal ischemic heart disease in women than in man ? The Rancho Bernardo study. JAMA. 1991;265:627-31.

26. Park JM, Bong HY, Jeong HI, Kim YK, Kim JY, Kwon O. Postprandial hypoglycemic effect of mulberry leaves in Gotokakizaki rats and counterpart control Wistar rats. Nutr Res Pract. 2009;3:272-8.

27. Jacobson TA, Miller M, Schaefer EJ. Hypertriglyceridemia and cardiovascular risk reduction. ClinTher. 2007:29:763-77.

28. Heidrich JE, Contos LM, Hunsaker LA, Deck LM, Vander Jagt DL. Inhibition of pancreatic cholesterase reduces cholesterol absorption in the hamster. BMC Pharmacol. 2004; doi: 10.1186/1471-2210-4-5

29. Birari RB, Bhutani KK. Pancreatic lipase inhibitors from natural sources: unexplored potential. Drug Discov Today. 2007;12:879-89.

30. Gotto Jr AM, Grundy SM. Lowering LDL Cholesterol: Questions From Recent Meta-Analyses and Subset Analyses of Clinical Trial Data Issues From the Interdisciplinary Council on Reducing the Risk for Coronary Heart Disease, Ninth Council Meeting. Circulation. 1999;99:1-7.

31. Kashyap SR, Defronzo RA. The Insulin resistance syndrome: physiological considerations. Diabetes Vasc Dis Res. 2007:4:13-9.

32. William M, Stephen B. The kidneys. Clinical chemistry. 6th ed. Philadephia: Mosby Elsevier; 2008. p. 69-93.

33. Lamb E, Neuwman DJ, Price C. Kidney function tests. In: Burtis CA, Ashwood ER, Burns DE, editors. Tietz textbook of clinical chemistry and molecular diagnostics. 4th ed. Philadelphia: Elsevier Saunders; 2006. p. $797-835$.

34. Parvizi MR, Parviz M, Tavangar SM, Soltani N, Kadkhodaee M, Seifi B, et al. Protective effect of magnesium on renal function in STZ-induced diabetic rats. J DiabetMetab Dis. 2014;13:84.

35. Panteghini M, Bais R, van Solinge WW. Enzymes. In: Burtis CA, Ashwood ER, Burns DE, editors. Tietz textbook of clinical chemistry and molecular diagnostics. 4th ed. Philadelphia: Elsevier Saunders; 2006. p. 597-643.

36. Senior JR. Monitoring for hepatotoxicity: what is the predictive value of liver "function" tests? Clin Pharmacol Ther. 2009;85:331-4.

37. Coates P. Liver function tests. Aust Fam Physician. 2011:40:113-5.

38. Whitehead MW, Hawkes ND, Hainsworth I, Kingham JG. A prospective study of the causes of notably raised aspartate aminotransferase of liver origin. Gut. 1999;45:129-33.

39. Harris EH. Elevated liver function tests in type 2 diabetes. Clin Diabetes. 2005:23:115-9.

40. Leeds JS, Forman EM, Morley S, Scott AR, Tesfaye S, Sanders DS. Abnormal liver function tests in patients with Type 1 diabetes mellitus: prevalence, clinical correlations and underlying pathologies. Diabetes Med. 2009;26: 1235-41.

41. Hollander P. Anti-Diabetes and Anti-Obesity Medications: Effects on Weight in People with Diabetes. Diabetes Spectrum. 2007:20:159-65. 